\title{
A Meta-Analysis of Work-Family Conflict and Various Outcomes With a Special Emphasis on Cross-Domain Versus Matching-Domain Relations
}

\author{
Fabienne T. Amstad, Laurenz L. Meier, Ursula Fasel, Achim Elfering, and \\ Norbert K. Semmer \\ University of Bern
}

\begin{abstract}
A literature review of studies analyzing work-family conflict and its consequences was conducted, and 427 effect sizes were analyzed meta-analytically. Work-family conflict was analyzed bidirectionally in terms of work interference with family (WIF) and family interference with work (FIW). We assessed 3 categories of potential outcomes: work-related outcomes, family-related outcomes, and domain-unspecific outcomes. Results show that WIF and FIW are consistently related to all 3 types of outcomes. Both types of interrole conflict showed stronger relationships to same-domain outcomes than to cross-domain outcomes. Thus, WIF was more strongly associated with work-related than with family-related outcomes, and FIW was more strongly associated with family-related than with work-related outcomes. In moderator analyses, parenthood could not explain variability in effect sizes. However, time spent at work did moderate the relationships between WIF and family-related outcomes, as well as FIW and domain-unspecific outcomes.
\end{abstract}

Keywords: work-family conflict, meta-analysis, well-being

Many studies have examined the relationship between work-family conflict and several potential consequences. Investigators have focused on wellbeing indicators, such as depression or strain (e.g., Kossek, Lautsch, \& Eaton, 2006), and on work, family, and life satisfaction (e.g., Aryee, Fields, \& Luk, 1999). Several meta-analyses of these findings have been reported (Allen, Herst, Bruck, \& Sutton, 2000; Ford, Heinen, \& Langkamer, 2007; Kossek \& Ozeki, 1998). For two reasons, however, we think that our meta-analysis can add to this literature. First, research in the domain of work-family conflict is growing at a fast rate (Eby, Casper, Lockwood, Bordeaux, \& Brinley, 2005). It therefore is important to update meta-analytic findings regularly (Ioannidis \& Lau, 2001). Second, none of the existing metaanalyses provided a comprehensive review of the literature in terms of (a) different directions of workfamily conflict, (b) diverse outcomes, and (c) poten-

This article was published Online First January 31, 2011. Fabienne T. Amstad, Laurenz L. Meier, Ursula Fasel, Achim Elfering, and Norbert K. Semmer, Department of Psychology, University of Bern, Switzerland.

Correspondence concerning this article should be addressed to Norbert K. Semmer, University of Bern, Department of Psychology, Muesmattstrasse 45, 3000 Bern 9, Switzerland. E-mail: norbert.semmer@psy.unibe.ch tial moderators. The purpose of this article is to fill this gap.

We begin with a discussion of work-family conflict and its dimensions as well as its diverse consequences for individual well-being at work and in family life. We then discuss potential moderators of the relationship between work-family conflict and its consequences before presenting the results of our meta-analysis.

\section{Work-Family Conflict}

Work-family conflict typically is defined as "a form of interrole conflict in which the role pressures from the work and family domains are mutually incompatible in some respect. That is, participation in the work (family) role is made more difficult by virtue of participation in the family (work) role" (Greenhaus \& Beutell, 1985, p. 77). This interrole conflict can take two directions (Frone, 2003): The work role can interfere with the family role (WIF), or the family role can interfere with the work role (FIW). Research has shown these concepts to be related (the meta-analysis by Mesmer-Magnus \& Viswesvaran, 2005, found a weighted mean observed correlation between WIF and FIW of $r_{w m}=.38$ ). Nevertheless, Mesmer-Magnus and Viswesvaran (2005) concluded that "despite some overlap, the two 
measures have sufficient unique variance to warrant independent examinations" (p. 228). Differential correlation patterns of WIF and FIW with outcomes have been found in longitudinal studies as well (e.g., Frone, 2000; Grandey, Cordeiro, \& Crouter, 2005; Hammer, Cullen, Neal, Sinclair, \& Shafiro, 2005; Kelloway, Gottlieb, \& Barham, 1999). Another reason for considering both directions of work-family conflict is that the prevalence of interrole conflicts is reported to be different, with WIF being more prevalent than FIW (Eagle, Miles, \& Icenogle, 1997; Frone, Russell, \& Cooper, 1992b). It therefore is important to differentiate between WIF and FIW so that the possibly different mechanisms underlying these interrole conflicts can be determined.

\section{Consequences of WIF and FIW}

Work-family conflict is often considered to be a potential source of stress that has negative effects on well-being and behavior (e.g., Geurts, Kompier, Roxburgh, \& Houtman, 2003). Potential consequences of work-family conflict can be divided into three distinct categories: work-related, family-related, and domain-unspecific outcomes (Bellavia \& Frone, 2005). ${ }^{1}$

Both directions of work-family conflict have been found to be associated with work-related outcomes, such as job satisfaction (e.g., Perrewé, Hochwarter, \& Kiewitz, 1999), organizational commitment (e.g., Aryee, Srinivas, \& Tan, 2005), intention to quit (e.g., Shaffer, Harrison, Gilley, \& Luk, 2001), burnout (e.g., Peeters, Montgomery, Bakker, \& Schaufeli, 2005), absenteeism (e.g., Kirchmeyer \& Cohen, 1999), work-related strain (e.g., Netemeyer, Brashear-Alejandro, \& Boles, 2004), and organizational citizenship behavior (OCB; e.g., Netemeyer, Maxham, \& Pullig, 2005), as well as family-related outcomes, such as marital satisfaction (e.g., Voydanoff, 2005b), family satisfaction (e.g., Cardenas, Major, \& Bernas, 2004), and family-related strain (e.g., Swanson \& Power, 1999). Finally, the third categorydomain-unspecific outcomes - also has been found to be related to both directions of work-family conflict; these outomes include life satisfaction (e.g., Greenhaus, Collins, \& Shaw, 2003), psychological strain (e.g., Kelloway et al., 1999), somatic complaints (e.g., Peeters, de Jonge, Janssen, \& van der Linden, 2004), depression (e.g., Vinokur, Pierce, \& Buck, 1999), and substance use or abuse (e.g., Grzywacz \& Bass, 2003).

Given that potential outcomes of work-family conflict may be found in the work domain, the family domain, or in domain-unspecific indicators, the ques- tion arises whether the domain of origin of a conflict is related to the outcome domain in a specific way. Put differently, is there a match in that WIF affects work-related outcomes more strongly than familyrelated outcomes, and vice versa, or are cross-domain associations more dominant in that FIW affects work-related outcomes more strongly than familyrelated outcomes, and vice versa? Competing models exist with regard to this issue, but no meta-analytic evidence is available so far.

\section{The Relationship Between WIF/FIW and Outcomes: Cross-Domain Versus Matching Hypothesis}

Frone, Russell, and Cooper (1992a) assumed a cross-domain relationship, implying that WIF predominantly affects the family domain, whereas FIW mainly affects the work domain. The rationale behind this assumption is that the conflict, although originating in one domain, is causing problems in the other domain. As a consequence, well-being related to this other life domain suffers. For example, individuals experiencing WIF cannot spend as much time with their family as they would like because of their job responsibilities. As a consequence, the quality of family life suffers, inducing family-related outcomes (e.g., family satisfaction) to decrease.

However, a "matching-hypothesis", which assumes that the primary effect of work-family conflict lies in the domain where the conflict originates, seems at least as plausible. According to this hypothesis, WIF should have stronger effects on workrelated outcomes and FIW should have stronger effects on family-related outcomes. The rationale for this assumption refers to appraisal, most notably attributional, processes. By definition, the cause of WIF (FIW) is seen in one's work (family). People are likely to dwell on the causes of work-family conflict, their characteristics, their consequences, ways of dealing with them, and so forth. To the extent that this occurs, people's thoughts are likely to be centered around the work (family) situation. Unless the situation can be adequately resolved (which would

\footnotetext{
${ }^{1}$ Because most of the studies are based on cross-sectional data, it would be more appropriate to talk of potential antecedents and outcomes, or of assumed antecedents and outcomes, referring to the causal structure implied by theoretical models about work-family conflict. For the sake of readability, however, we use terms such as outcome and consequence with the understanding that what is meant are potential outcomes.
} 
eliminate the work-family conflict), these thoughts are likely to be ruminative in character, implying a negative affective tone, which, if experienced frequently, may lead to strain. Furthermore, specific attributions regarding the causes for the work (family) situation being so stressful may elicit further emotional reactions. Thus, if one's work overload is considered to be responsible for having too little time with one's family, one might feel anger and resentment against one's organization, or one's supervisor, for being assigned too much work for the time and resources available (Moore, 2000; see also Weiner, 1985). That primary reactions are connected to the perceived source of one's problem is corroborated by results showing that counterproductive work behavior (CWB) tends to be specifically targeted at the source of conflicts (i.e., conflicts with supervisors are associated more strongly with CWB toward the organization, and conflicts with coworkers are associated more strongly with interpersonal CWB; BrukLee \& Spector, 2006).

In sum, negative affective reactions (and their possible behavioral consequences, such as quitting) are likely to center around the domain that is seen as causing the problem, implying that strain reactions should be dominant with regard to this domain. This is not to say that effects on outcomes referring to the other domain will not occur, but they are seen as indirect rather than direct.

Both types of outcomes, however, are likely to generalize: Life satisfaction is known to be associated with both job satisfaction (Spector, 1997) and family satisfaction (Diener \& Diener, 1995). This assumption corresponds to Warr's (2007) argument postulating direct effects of work stress on workrelated well-being/strain and indirect effects on more general indicators of well-being/strain, which are mediated by work-related strain. Warr's assumption is supported by empirical evidence (e.g., Kelloway \& Barling, 1991; cf. Warr, 2007).

Empirical support for a cross-domain effect has been found in several studies (for a meta-analysis, see Ford et al., 2007). However, these studies did not test the cross-domain effect against the competing matching hypothesis, which assumes that the effect is stronger for dependent variables that are in the same domain as the stressors (Kelloway \& Barling, 1991). Therefore, support for the cross-domain hypothesis remains ambiguous. Evidence supporting the matching hypothesis has been provided by Kossek and Ozeki (1998). Their meta-analysis showed a consistent negative relationship of both WIF and FIW with job satisfaction as well as life satisfaction. However, the relationship was slightly stronger for job satisfaction and WIF, as compared with job satisfaction and FIW, yielding more support for the matching hypothesis than for the cross-domain hypothesis. We feel that there are stronger arguments for the matching than for the cross-domain hypothesis.

\section{Meta-Analytic Findings}

Four meta-analyses with regard to the relationship between work-family conflict and different outcomes so far have been reported (Allen et al., 2000; Ford et al., 2007; Kossek \& Ozeki, 1998, 1999). Two further meta-analyses concerned with the work-family interface dealt with other questions, such as antecedents of WIF and FIW (Byron, 2005) and the convergence of WIF and FIW measures (Mesmer-Magnus \& Viswesvaran, 2005). A brief summary of the four meta-analyses that dealt with similar questions as ours clarifies why our meta-analysis can add valuable information.

Kossek and Ozeki (1998) investigated the relationship of WIF/FIW with life and job satisfaction, but not with family or marital satisfaction. As mentioned above, they found that WIF/FIW was related to life satisfaction slightly more than to job satisfaction. Kossek and Ozeki (1999) found only a few studies that assessed work-related outcomes other than job satisfaction $(k=0-7)$. Ford et al. (2007) metaanalytically tested the cross-domain relations among work/family antecedents, WIF/FIW, and work/family satisfaction. WIF (FIW) seemed to mediate the relationship between work (family) stressors and family (job) satisfaction. It remains unclear, however, whether that holds in general, that is, for several outcomes, or whether it is confined to satisfaction. Finally, Allen et al. (2000) found a consistent negative relationship between WIF and three types of outcomes: work-related, non-work-related, and stress-related. However, their analysis was confined to one direction only, which was WIF.

Given these gaps in existing meta-analyses, we wanted to provide a more comprehensive picture by analyzing the relationship between both directions of work-family conflict and several domain-specific as well as domain-unspecific outcomes. Furthermore, we tested the cross-domain hypothesis as well as the matching hypothesis. Figure 1 shows all relationships we tested. In addition, we tested some possible moderators that may influence the relationship between WIF/FIW and its consequences; these are presented next. 


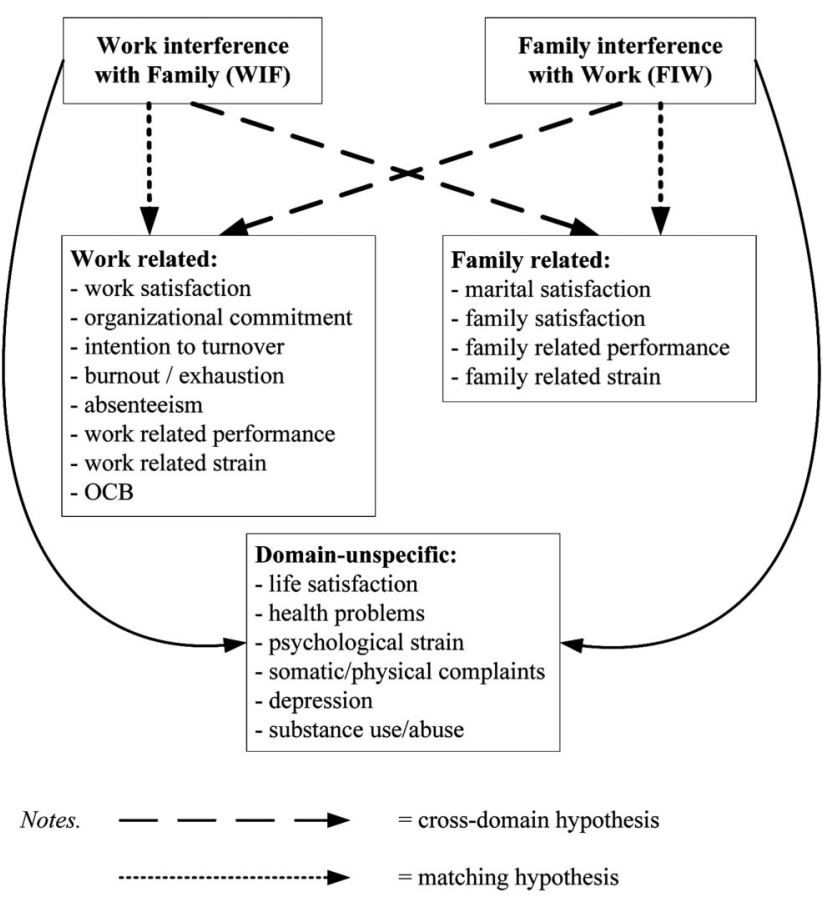

Figure 1. Framework of study variables and hypotheses. $\mathrm{OCB}=$ organizational citizenship behavior.

\section{Moderators}

We tested two possible moderators of the associations depicted in Figure 1, which are (a) time spent at work and (b) parenthood.

\section{Time Spent at Work}

Theoretical models (e.g., Barnett, 1998; Frone et al., 1992a; Greenhaus \& Beutell, 1985) and empirical evidence (Fox \& Dwyer, 1999; Geurts, Rutte, \& Peeters, 1999; Jacobshagen, Amstad, Semmer, \& Kuster, 2005; Major, Klein, \& Ehrhart, 2002) show that the amount of time spent at work has a direct effect on work-family conflict. The meta-analysis of Byron (2005) showed a corrected mean correlation of $r_{w m}=.26$ between time spent at work and WIF. For FIW, no significant mean correlation was found. Whereas these studies examined the direct effect of time spent at work on work-family conflict, we argue that time spent at work also can have an impact on the relationship between work-family conflict and its consequences. Higgins, Duxbury, and Johnson (2000) found that, compared with full-time work, part-time work was associated with individual time management in that part time workers perceived less difficulty managing their time than did full-time workers. Working part-time leaves an individual more time for family, which can help restore resources such as family support (e.g., Luk \& Shaffer, 2005). These resources might attenuate the impact of work-family conflict on one's well-being or behavior. Therefore, we propose that working fewer hours would buffer the negative effect of WIF/FIW on different outcomes.

\section{Parenthood}

Several studies have found that parents experience more WIF and FIW than individuals without children (for a meta-analysis, see Byron, 2005). Besides this direct effect, we suggest that child-care responsibilities affect the relationship between WIF/FIW and different outcomes. Coping with conflicts between life domains often involves trade-offs between these domains. For example, individuals experiencing FIW are likely to show work-related withdrawal behavior, 
like being late or doing family calls at work (Behson, 2002a; Hammer, Bauer, \& Grandey, 2003). Conversely, when experiencing WIF, individuals may work at home or come home late. Parents have more family-related demands, particularly when they have young children (Higgins et al., 2000). These additional family-related demands are likely to make such trade-offs more difficult. For example, it is more difficult to come home late when there are children waiting for dinner at home. As a result, such coping strategies can be expected to fail more often than when there are no child-care responsibilities. Unsuccessful coping is likely to affect well-being. Therefore, we propose that child-care responsibility enhances the relationship between WIF/FIW and different outcomes.

\section{The Present Study}

Summarizing these considerations, we analyzed three groups of hypotheses. They relate (a) to associations between work-family conflict and different types of outcomes, (b) to differential relationship of WIF/FIW with work- versus family-related outcomes, and (c) to potential moderators. Concerning the relationship between WIF/FIW and different outcomes, we updated the Allen et al. (2000) study concerning WIF. $^{2}$ But we expand these results by studying the relationship between different outcomes with FIW as well.

\section{Work-Family Conflict and Different Types of Outcomes (H1)}

Hypothesis 1a: WIF is associated with work-related outcomes, family-related outcomes, and domain-unspecific outcomes.

Hypothesis 1b: FIW is associated with work-related outcomes, family-related outcomes, and domain-unspecific outcomes.

\section{Differential Associations (H2)}

Concerning differences between the relationships of domain-specific outcomes with WIF and FIW, we propose that the results correspond to the matching rather than the cross-domain hypothesis.

Hypothesis 2a: WIF is more strongly related to work-related than to family-related outcomes.
Hypothesis $2 b$ : FIW is more strongly related to family-related than to work-related outcomes.

\section{Moderating Effects (H3)}

The last group of hypotheses concerns two potential moderators of the relationships between workfamily conflict and our different outcomes. We predicted long working hours to enhance the negative association between work-family conflict and outcomes, whereas parenthood is supposed to enhance the negative relationship between work-family conflict and outcomes.

Hypothesis 3a: Working hours have a moderating effect on the relationship among WIF/FIW and work-related, family-related, and domainunspecific outcomes, with relationships being stronger for longer hours.

Hypothesis 3b: Parenthood has a moderating effect on the relationship between WIF/FIW and work-related, family-related, and domainunspecific outcomes, with relationships being stronger for parents.

\section{Method}

\section{Literature Search}

Using a threefold search strategy for identifying relevant articles, we first conducted a computer search using the PsycINFO database. The key words work and family conflict yielded 356 studies published in industrial and organizational psychology and organizational behavior (IO/OB) and non-IO/OB journals. Other key words, like interrole conflict or multiple role stress did not yield additional studies. Second, we conducted a manual search in the following journals: Journal of Applied Psychology, Journal of Organizational Behavior, Journal of Marriage and Family, Journal of Vocational Behavior, Organizational Behavior and Human Decision Processes, Academy of Management Journal, Sex Roles, and Community, Work \& Family. More than $74 \%$ of all

\footnotetext{
${ }^{2}$ Following Allen et al. (2000), we categorize all outcomes into three categories: work-related outcomes, familyrelated outcomes, and domain-unspecific outcomes. We chose slightly different categories than Allen et al. because their last category of stress-related outcomes was partly confounded with domain-specific variables (e.g., workrelated stress was in the stress-related outcome category).
} 
articles on the work-family domain between 1980 and 2003 were published in these journals (Casper, Eby, Bordeaux, Lockwood, \& Lambert, 2007). We also included the two leading European journals in the field of work and organizational psychology, the Journal of Occupational and Organizational Psychology and the European Journal of Work and Organizational Psychology. Finally, we inspected the reference list of all articles and recent reviews (e.g., Eby et al., 2005) to identify more articles relevant to our study.

\section{Inclusion Criteria}

We included only published (or in press) studies, thus ensuring peer review (Kossek \& Ozeki, 1998). The language had to be English. In addition, we set a timeframe from January 1999 to September 2006. Furthermore, studies had to assess work-family conflict in a direction-specific way, which is WIF or FIW; if the direction was not clear or if the measure referred to a mixture of both directions, the study was not considered. This criterion led to the exclusion of 41 effect sizes. Studies also had to include quantitative outcome measures. Because concepts such as work-to-personal life conflict, work-to-nonwork conflict, and work-to-life conflict are used interchangeably with WIF in the literature (Geurts \& Demerouti, 2003), they were treated as equivalent with WIF provided that a careful inspection of the items confirmed that they were, indeed, measuring the same kind of conflict. Only studies that measured a current conflict were included, whereas studies that focused on a probable conflict in the future were excluded. In addition, because the positive side of the interface of work and family, namely work-family balance, work-family enhancement, or work-family facilitation, cannot be regarded as the opposite of a workfamily conflict (for an overview, see Frone, 2003), studies analyzing only the positive side of the interface were excluded. If studies reported no correlations (e.g., only regression coefficients), we contacted the authors; if they did not provide correlation coefficients, the study was not considered. Twelve studies were excluded for these reasons. In total, 427 correlations from 98 articles were included, 261 for WIF and 166 for FIW.

\section{Coding}

Effect sizes were coded for WIF and FIW with respect to a specific outcome. We did not code workfamily conflict according to its time-based, strain- based, and behavior-based nature, which was suggested by Greenhaus and Beutell (1985), because this distinction is very rarely used (Carlson, Kacmar, \& Williams, 2000). If a study did distinguish different forms of WIF or FIW, we pooled the results to obtain an overall measure of WIF or FIW.

All variables coded in this meta-analysis are shown in Table 1, as well as the central tendency (median and mean) of these variables across all studies and the interrater reliability. An overview of all studies used in this meta-analysis, including information about author(s), publication year, sample characteristics, sample size, bivariate correlations, measurement of the conflict, and measurement of the outcome, can be obtained from the first author. The following categories of variables were coded:

Source. All studies were published in peerreviewed journals. The majority of the studies were published in 2004. Some studies used subsamples from larger surveys to analyze the relationship between WIF/FIW and different outcomes. If different studies of the same survey reported the same relationships (this means the same type of interrole conflict and the same outcome), we included only the study with the larger subsample in the meta-analysis to prevent an overrepresentation of a single survey (Lipsey \& Wilson, 2001; Rosenthal, 1995).

Design. Most of the studies were cross-sectional (355 of 427 correlations were based on crosssectional studies). For longitudinal studies, we coded cross-sectional results from the baseline. If information about WIF/FIW or an outcome variable was not assessed for the baseline, information was taken from the follow-ups. The aim was to stay as far as possible with the cross-sectional results to make studies as comparable as possible. Furthermore, this strategy was used to avoid biases from sample attrition.

Sample information. Most of the coded variables are concerned with sample information. The central tendency of the variables that refer to sample characteristics is shown in Table 1. Most of the studies were conducted in North America, with mostly Caucasian participants. On average, half of the sample was female. Most of the participants were married, lived in dual-earner relationships, had children, and worked full time.

\section{Analysis}

We followed the meta-analytical procedure of Hunter and Schmidt (1990; Hunter, Schmidt, \& Jackson, 1982), using Schwarzer's (1989) META program. We calculated effect size summary statistics 
Table 1

Variables Included in the Meta-Analysis Including Central Tendency and Reliability

\begin{tabular}{|c|c|c|c|}
\hline \multirow[b]{2}{*}{ Variable } & \multicolumn{2}{|c|}{ Central tendency } & \multirow{2}{*}{$\begin{array}{l}\text { Interrater } \\
\text { reliability } \\
\quad(\%)\end{array}$} \\
\hline & Mean & Median & \\
\hline \multicolumn{4}{|l|}{ Source } \\
\hline Bibliographic reference & - & - & 100 \\
\hline Publication year & 2003.06 & 2004 & 100 \\
\hline Type of publication & - & Journal & 100 \\
\hline Subsample & - & - & 100 \\
\hline \multicolumn{4}{|l|}{ Design } \\
\hline Cross-sectional vs. longitudinal & - & Cross-sectional & 100 \\
\hline \multicolumn{4}{|l|}{ Sample } \\
\hline Sample size $(n)$ & 527.97 & 267 & 94.1 \\
\hline Country & - & North America & 100 \\
\hline Participation rate & 55.61 & 53.50 & 91.1 \\
\hline Women $(\%)$ & 52.80 & 50.00 & 91.1 \\
\hline Mean age (years) & 38.54 & 38.95 & 100 \\
\hline Married/long relationship (\%) & 80.77 & 80.50 & 97.1 \\
\hline Dual-earner couples $(\%)$ & 86.68 & 100.00 & 100 \\
\hline With children $(\%)$ & 76.78 & 79.00 & 97.1 \\
\hline Single parents $(\%)$ & 4.20 & 4.20 & 100 \\
\hline Full-time workers $(\%)$ & 83.68 & 92.00 & 94.1 \\
\hline Mean housework time (hours per week) & 25.00 & 27.50 & 100 \\
\hline Mean work time (hours per week) & 42.46 & 43.00 & 97.1 \\
\hline Type of job & - & $>50 \%$ White-collar & 100 \\
\hline Organizational tenure (years) & 8.00 & 8.14 & 91.1 \\
\hline Ethnicity/race & - & $>50 \%$ Caucasian & 100 \\
\hline \multicolumn{4}{|l|}{ WIF/FIW } \\
\hline Type of conflict (WIF/FIW) & $2.71 / 2.12$ & $2.82 / 2.09$ & 100 \\
\hline Direction of conflict measured (only WIF, only FIW, & & & \\
\hline both directions) & - & Both directions & 100 \\
\hline Instrument used & - & - & 100 \\
\hline Reliability & - & - & 100 \\
\hline \multicolumn{4}{|l|}{ Outcomes } \\
\hline Type of outcome & - & - & 100 \\
\hline Instrument used & - & - & 100 \\
\hline Reliability & - & - & 100 \\
\hline \multicolumn{4}{|l|}{ Effect size } \\
\hline Type of effect size & - & Correlation & 100 \\
\hline Effect size & - & - & 100 \\
\hline
\end{tabular}

Note. $\quad$ WIF $=$ work interference with family; FIW = family interference with work.

for random effect models, correcting scores of each study for reliability (Hunter \& Schmidt, 2000). For each outcome variable, we calculated an effect size weighted for sample size in addition to the unweighted effect size. The effect size models for each direction of the conflict were calculated separately. The weighted effect size models are presented in Tables 2 and 3. Furthermore, correlations for the relationship between WIF/FIW and the different outcomes (work-related outcomes, family-related outcomes, and domain-unspecific outcomes) were estimated separately. Correlations that were derived from the same sample and were, therefore, dependent (Hunter et al., 1982) were pooled using
Fisher's $Z$ transformation (Bortz, 1993). A significant relationship between work-family conflict and an outcome variable is assumed when the $95 \%$ confidence interval of the weighted correlation does not include zero.

Population effect sizes are only interpretable in a reliable way if the underlying data set can be seen as homogeneous. If the homogeneity is not sufficient, the effect size should be tested for potential moderators (Hunter et al., 1982). Homogeneity was tested with two criteria: First, the residual standard deviation should be smaller than one quarter of the population effect size (Schwarzer, 1989; Stoffelmayr, Dillavou, \& Hunter, 1983). This criterion is based on the 
Table 2

Results of the Meta-Analysis for Work Interference With Family (WIF)

\begin{tabular}{|c|c|c|c|c|c|c|c|}
\hline \multirow[b]{2}{*}{ Outcome } & \multirow[b]{2}{*}{$k$} & \multirow[b]{2}{*}{$N$} & \multirow[b]{2}{*}{$\begin{array}{c}\text { Weighted mean } \\
\text { correlation }(95 \% \mathrm{CI})\end{array}$} & \multirow[b]{2}{*}{$N_{\mathrm{FS}}$} & \multicolumn{3}{|c|}{ Homogeneity } \\
\hline & & & & & $S D_{\text {Res }}$ & $\sigma_{\mathrm{e}}^{2} / \sigma_{\Delta}^{2}(\%)$ & $95 \% \mathrm{CrI}$ \\
\hline \multicolumn{8}{|l|}{ Work-related outcome } \\
\hline Work satisfaction & 54 & 25,114 & $-.26[-.273,-.250]^{*}$ & 228.25 & .087 & 19.57 & {$[-0.513,-0.109]^{\mathrm{d}}$} \\
\hline Orgizational commitment & 14 & 7,400 & $-.17[-.187,-.142]^{*}$ & 32.07 & .128 & 9.82 & {$[-0.505,0.105]$} \\
\hline Intention to turnover & 24 & 10,961 & $.21[.191, .227]^{*}$ & 76.30 & .092 & 19.06 & {$[0.035,0.457]^{\mathrm{d}}$} \\
\hline Burnout/exhaustion & 15 & 9,177 & $.38[.361, .396]^{*}$ & $98.60^{\mathrm{a}}$ & .097 & 10.95 & {$[0.226,0.680]^{\mathrm{d}}$} \\
\hline Absenteeism & 5 & 6,351 & $.03[.007, .056]^{*}$ & $<1$ & $.000^{\mathrm{b}}$ & $100.00^{\mathrm{c}}$ & {$[0.034,0.034]^{\mathrm{d}}$} \\
\hline Work-related performance & 10 & 2,343 & $-.11[-.149,-.068]^{*}$ & 11.76 & .150 & 15.59 & {$[-0.484,0.223]$} \\
\hline Work-related stress & 16 & 8,497 & $.49[.477, .510]^{*}$ & $141.97^{\mathrm{a}}$ & $.114^{\mathrm{b}}$ & 6.75 & {$[0.316,0.834]^{\mathrm{d}}$} \\
\hline Career satisfaction & 4 & 1,383 & $-.09[-.141,-.036]^{*}$ & 3.08 & .045 & 58.66 & {$[-0.220,-0.001]^{\mathrm{d}}$} \\
\hline OCB & 3 & 550 & $-.63[-.679,-.578]^{*}$ & $34.86^{\mathrm{a}}$ & .252 & 1.70 & {$[-1.000,-0.135]^{\mathrm{d}}$} \\
\hline \multicolumn{8}{|l|}{ Family-related outcome } \\
\hline Marital satisfaction & 12 & 6,851 & $-.17[-.192,-.146]^{*}$ & 28.61 & $.022^{\mathrm{b}}$ & $78.04^{\mathrm{c}}$ & {$[-0.248,-0.160]^{\mathrm{d}}$} \\
\hline Family satisfaction & 13 & 6,820 & $-.18[-.199,-.153]^{*}$ & 32.83 & $.041^{\mathrm{b}}$ & 51.81 & {$[-0.301,-0.117]^{\mathrm{d}}$} \\
\hline Family-related performance & 3 & 803 & $-.18[-.246,-.111]^{*}$ & 7.76 & $.000^{\mathrm{b}}$ & $100.00^{\mathrm{c}}$ & {$[-0.218,-0.218]^{\mathrm{d}}$} \\
\hline Family-related stress & 7 & 1,548 & $.23[.184, .279]^{*}$ & 25.44 & $.053^{\mathrm{b}}$ & 58.71 & {$[0.155,0.405]^{\mathrm{d}}$} \\
\hline \multicolumn{8}{|l|}{ Domain-unspecific outcome } \\
\hline Life satisfaction & 12 & 3,143 & $-.31[-.338,-.275]^{*}$ & 61.65 & .094 & 25.84 & {$[-0.580,-0.144]^{\mathrm{d}}$} \\
\hline Health problems & 4 & 5,076 & $.28[.253, .304]^{*}$ & 18.31 & .185 & 1.90 & {$[-0.103,0.766]$} \\
\hline Psychological strain & 18 & 8,039 & $.35[.326, .365]^{*}$ & $106.37^{\mathrm{a}}$ & .093 & 16.42 & {$[0.203,0.626]^{\mathrm{d}}$} \\
\hline Somatic/physical symptoms & 18 & 8,665 & $.29[.268, .306]^{*}$ & 85.34 & $.067^{\mathrm{b}}$ & 27.75 & {$[0.196,0.513]^{\mathrm{d}}$} \\
\hline Depression & 14 & 9,869 & $.23[.209, .247]^{*}$ & 49.78 & .103 & 10.77 & {$[0.033,0.512]^{\mathrm{d}}$} \\
\hline Substance use/abuse & 3 & 4,900 & $.08[.048, .104]^{*}$ & 1.56 & .022 & 56.12 & {$[0.071,0.175]^{\mathrm{d}}$} \\
\hline Stress & 6 & 5,347 & $.54[.515, .553]^{*}$ & $58.14^{\mathrm{a}}$ & $.115^{\mathrm{b}}$ & 3.43 & {$[0.360,0.884]^{\mathrm{d}}$} \\
\hline Anxiety & 3 & 4,804 & $.14[.111, .167]^{*}$ & 5.34 & .055 & 16.74 & {$[0.040,0.300]^{\mathrm{d}}$} \\
\hline Work-related outcome & 89 & 41,879 & $-.29[-.303,-.285]^{*}$ & 433.91 & .153 & 6.95 & {$[-0.711,0.010]$} \\
\hline Family-related outcome & 31 & 14,945 & $-.18[-.194,-.163]^{*}$ & 79.90 & $.035^{\mathrm{b}}$ & 60.85 & {$[-0.294,-0.136]^{\mathrm{d}}$} \\
\hline Domain-unspecific outcome & 56 & 32,411 & $-.32[-.328,-.308]^{*}$ & $300.11^{\mathrm{a}}$ & .153 & 5.52 & {$[-0.747,-0.019]^{\mathrm{d}}$} \\
\hline
\end{tabular}

Note. $\quad k=$ number of effect sizes; $N=$ total sample size; $95 \% \mathrm{CI}=95 \%$ confidence interval; $N_{\mathrm{FS}}=$ number of fail-safe; $S D_{\mathrm{Res}}=$ residual standard deviation; $\sigma_{\mathrm{e}}^{2} / \sigma_{\Delta}^{2}($ in $\%)=$ percentage of variance explained with the sample error; $95 \% \mathrm{CrI}=$ $95 \%$ credibility interval; OCB $=$ organizational citizenship behavior.

${ }^{\mathrm{a}}$ Criterion for plausibility accomplished: Fail-safe $N>5 * k+10 .{ }^{\mathrm{b}}$ Criterion for homogeneity by Stoffelmayr et al. (1983) accomplished: $S D_{\text {Res }}<1 / 4$ of population effect size. ${ }^{c}$ Criterion for homogeneity by Hunter et al. (1982) accomplished: $\sigma_{\mathrm{e}}^{2} / \sigma_{\Delta}^{2} \geq 75$. ${ }^{\mathrm{d}}$ Criterion for homogeneity by Whitener (1990) accomplished: Zero not included in the $95 \%$ credibility interval.

* Significant; zero not included in the $95 \%$ confidence interval.

idea that not only the percentage of variance of the sampling error should be taken into account, but also the actual amount of variance (McDaniel, Hirsh, Schmidt, Raju, \& Hunter, 1986). Nevertheless, the percentage of variance of the sampling error is also described in Tables 2 and 3 as additional information. Second, a correlation is often assumed to be homogeneous if the $95 \%$ credibility interval does not include zero (Whitener, 1990). However, this latter criterion is a matter of considerable controversy (Koslowsky \& Sagie, 1993). Furthermore, different indicators of homogeneity often lead to different conclusions. Given this situation, we decided to assume heterogeneity if any of the two criteria indicated heterogeneity.

\section{Moderator Analysis}

Two possible moderators were analyzed: working hours and parenthood. Parenthood was coded as the percentage of individuals in the sample with children. Working hours per week were coded in terms of the sample mean. The moderator variables were sample based (vs. effect size based). Because several effect sizes were derived from the same sample, implying dependent data, we calculated the moderator analyses using multilevel modeling, which takes the dependent data structure into account. We used HLM6.06 (Raudenbush, Bryk, Cheong, \& Congdon, 2004). On Level 1, we had a 
Table 3

Results of the Meta-Analysis for Family Interference With Work (FIW)

\begin{tabular}{|c|c|c|c|c|c|c|c|}
\hline \multirow[b]{2}{*}{ Outcome } & \multirow[b]{2}{*}{$k$} & \multirow[b]{2}{*}{$N$} & \multirow{2}{*}{$\begin{array}{c}\text { Weighted mean } \\
\text { correlation }(95 \% \mathrm{CI})\end{array}$} & \multirow[b]{2}{*}{$N_{\mathrm{FS}}$} & \multicolumn{3}{|c|}{ Homogeneity } \\
\hline & & & & & $S D_{\text {Res }}$ & $\sigma_{\mathrm{e}}^{2} / \sigma_{\Delta}^{2}($ in $\%)$ & $95 \% \mathrm{CrI}$ \\
\hline \multicolumn{8}{|l|}{ Work-related outcome } \\
\hline Work satisfaction & 35 & 19,180 & $-.13[-.148,-.120]^{*}$ & 58.92 & .062 & 31.73 & {$[-0.312,-0.018]^{\mathrm{d}}$} \\
\hline Organizational commitment & 10 & 5,178 & $-.15[-.177,-.124]^{*}$ & 20.14 & .055 & 37.67 & {$[-0.329,-0.057]^{\mathrm{d}}$} \\
\hline Intention to turnover & 16 & 8,636 & $.17[.147, .188]^{*}$ & 37.50 & .054 & 37.50 & {$[0.077,0.329]^{\mathrm{d}}$} \\
\hline Burnout/exhaustion & 6 & 5,885 & $.27[.244, .292]^{*}$ & 26.18 & $.039^{\mathrm{b}}$ & 37.06 & {$[0.239,0.420]^{\mathrm{d}}$} \\
\hline Absenteeism & 5 & 6,351 & $.09[.064, .113]^{*}$ & 3.82 & .057 & 19.46 & {$[-0.025,0.218]$} \\
\hline Work-related performance & 8 & 2,042 & $-.20[-.245,-.161]^{*}$ & 24.50 & .093 & 29.20 & {$[-0.476,-0.028]^{\mathrm{d}}$} \\
\hline Work-related stress & 13 & 5,562 & $.28[.250, .299]^{*}$ & 58.38 & .122 & 11.81 & {$[0.043,0.629]^{\mathrm{d}}$} \\
\hline Career satisfaction $^{\mathrm{e}}$ & - & - & - & - & - & - & - \\
\hline OCB & 2 & 452 & $-.54[-.606,-.476]^{*}$ & 19.78 & $.064^{\mathrm{b}}$ & 29.90 & {$[-0.744,-0.461]^{\mathrm{d}}$} \\
\hline \multicolumn{8}{|l|}{ Family-related outcome } \\
\hline Marital satisfaction & 5 & 3,027 & $-.29[-.323,-.257]^{*}$ & 24.02 & $.029^{\mathrm{b}}$ & 61.44 & {$[-0.396,-0.279]^{\mathrm{d}}$} \\
\hline Family satisfaction & 12 & 6,737 & $-.21[-.237,-.191]^{*}$ & 39.42 & .063 & 29.19 & {$[-0.408,-0.117]^{\mathrm{d}}$} \\
\hline Family-related performance & 3 & 803 & $-.02[-.087, .052]$ & $<1$ & .070 & 43.11 & {$[-0.192,0.149]$} \\
\hline Family-related stress & 5 & 1,123 & $.21[.154, .266]^{*}$ & 16.06 & .271 & 5.22 & {$[-0.406,0.931]$} \\
\hline \multicolumn{8}{|l|}{ Domain-unspecific outcome } \\
\hline Life satisfaction & 9 & 2,666 & $-.22[-.252,-.179]^{*}$ & 29.79 & $.047^{\mathrm{b}}$ & 57.74 & {$[-0.373,-0.160]^{\mathrm{d}}$} \\
\hline Health problems & 4 & 5,076 & $.24[.214, .266]^{*}$ & 15.18 & .083 & 9.27 & {$[0.094,0.477]^{\mathrm{d}}$} \\
\hline Psychological strain & 8 & 3,840 & $.21[.180, .240]^{*}$ & 25.60 & $.028^{\mathrm{b}}$ & 71.13 & {$[0.191,0.312]^{\mathrm{d}}$} \\
\hline Somatic/physical symptoms & 4 & 2,054 & $.14[.099, .184]^{*}$ & 7.35 & $.021^{\mathrm{b}}$ & $81.09^{c}$ & {$[0.127,0.227]^{\mathrm{d}}$} \\
\hline Depression & 10 & 6,712 & $.22[.193, .239]^{*}$ & 33.26 & $.029^{\mathrm{b}}$ & 62.38 & {$[0.204,0.327]^{\mathrm{d}}$} \\
\hline Substance use/abuse & 2 & 4,686 & $.10[.073, .130]^{*}$ & 2.05 & $.014^{\mathrm{b}}$ & 68.46 & {$[0.104,0.173]^{\mathrm{d}}$} \\
\hline Stress & 4 & 3,037 & $.39[.359, .419]^{*}$ & 27.15 & $.043^{\mathrm{b}}$ & 32.71 & {$[0.451,0.530]^{\mathrm{d}}$} \\
\hline Anxiety & 3 & 4,804 & $.19[.159, .214]^{*}$ & 8.19 & $.016^{\mathrm{b}}$ & 69.55 & {$[0.203,0.259]^{\mathrm{d}}$} \\
\hline Work-related outcome & 57 & 27,219 & $-.16[-.174,-.150]^{*}$ & 127.66 & .093 & 18.53 & {$[-0.423,0.026]$} \\
\hline Family-related outcome & 23 & 11,038 & $-.22[-.236,-.200]^{*}$ & 77.39 & .120 & 11.55 & {$[-0.554,0.021]$} \\
\hline Domain-unspecific outcome & 33 & 21,560 & $-.23[-.245,-.220]^{*}$ & 120.43 & .083 & 16.63 & {$[-0.484,-0.088]^{\mathrm{d}}$} \\
\hline
\end{tabular}

Note. $\quad k=$ number of effect sizes; $N=$ total sample size; $95 \% \mathrm{CI}=95 \%$ confidence interval; $N_{\mathrm{FS}}=$ number of fail-safe; $S D_{\text {Res }}=$ residual standard deviation; $\sigma_{\mathrm{e}}^{2} / \sigma_{\Delta}^{2}($ in $\%)=$ percentage of variance explained with the sample error; $95 \% \mathrm{CrI}=$ $95 \%$ credibility interval; OCB $=$ organizational citizenship behavior.

${ }^{\text {a }}$ Criterion for plausibility accomplished: Fail-safe $N>5 * k+10 . \quad{ }^{\text {b }}$ Criterion for homogeneity by Stoffelmayr et al. (1983) accomplished: $S D_{\text {Res }}<1 / 4$ of population effect size. ${ }^{\mathrm{c}}$ Criterion for homogeneity by Hunter et al. (1982) accomplished: $\sigma_{\mathrm{e}}^{2} / \sigma_{\Delta}^{2} \geq 75$. ${ }^{\mathrm{d}}$ Criterion for homogeneity by Whitener (1990) accomplished: Zero not included in the $95 \%$ credibility interval. ${ }^{\mathrm{e}}$ Only one study $(k=1)$; therefore, we do not report the results.

* Significant; zero not included in the $95 \%$ confidence interval.

total of 427 effect sizes, whereas on Level 2 we had 112 samples.

\section{Results}

\section{Work-Family Conflict (WIF/FIW) and Different Outcomes}

WIF. Results concerning WIF and all outcome variables are shown in Table 2. All weighted mean correlations were in the expected direction. In all cases, WIF was negatively associated with wellbeing and performance, no matter whether the indicators were domain-specific or domain-unspecific. Furthermore, all correlations were significant, which means that zero was not included in the $95 \%$ confi- dence interval. Overall, the strongest relationship was found between WIF and domain-unspecific outcomes $\left(r_{w m}=-.32\right)$, followed by work-related outcomes $\left(r_{w m}=-.29\right)$ and family-related outcomes $\left(r_{w m}=\right.$ -.18). Within the three categories of outcomes, the strongest relationship among domain-unspecific outcomes was between WIF and general stress $\left(r_{w m}=\right.$ $.54)$, but only six studies analyzed this relationship. Among work-related outcomes, OCB showed the strongest relationship with WIF $\left(r_{w m}=-.63\right)$. However, this result is based on only three studies, with a total sample size of 550. Concerning family-related outcomes, the strongest relationship was between WIF and family-related stress $\left(r_{w m}=.23\right)$, based on seven studies. Altogether, WIF was associated with 
all outcomes from all three domains. Hypothesis 1a therefore is supported.

FIW. Table 3 describes the results for FIW and all outcomes. Again, all relationships were in the expected direction: FIW was negatively associated with well-being and performance. Furthermore, all relationships except one differed significantly from zero. The exception was family-related performance $\left(r_{w m}=-.02, n s\right)$, which was based on only three studies, however (with a total sample size of 803). Similar to the findings for WIF, the strongest relationship overall involved domain-unspecific outcomes $\left(r_{w m}=-.23\right)$, followed by family-related outcomes $\left(r_{w m}=-.22\right)$ and work-related outcomes $\left(r_{w m}=-.16\right)$. FIW has been investigated less frequently than WIF. Therefore, most results concerning single indicators are based on few studies. The strongest relationships were shown for OCB $\left(r_{w m}=-.54\right.$; three studies), general stress $\left(r_{w m}=.39\right.$; four studies), work-related stress $\left(r_{w m}=.28 ; 13\right.$ studies $)$, marital satisfaction $\left(r_{w m}=-.29\right.$; five studies), burnout/exhaustion $\left(r_{w m}=.27\right.$; six studies $)$, and health problems $\left(r_{w m}=.24\right.$; four studies). Except for workrelated stress, these results cannot be considered to be very robust; thus, the strength of the association between single outcome indicators and FIW has to be treated with caution. Nevertheless, the overall outcome categories (family-related outcomes, workrelated outcomes, and domain-unspecific outcomes) can be interpreted, and we conclude that Hypothesis $1 \mathrm{~b}$ is supported.

\section{Cross-Domain Relations Versus Matching Hypothesis}

For both WIF and FIW, the strongest relationship was found with domain-unspecific outcomes. Contrary to the cross-relationship hypothesis (Ford et al., 2007; Frone et al., 1992a), WIF was more strongly related to work-related outcomes than to familyrelated outcomes, and FIW was more strongly related to family-related outcomes than to work-related outcomes. In both cases, this difference was significant, as indicated by the nonoverlapping confidence intervals. These results confirm the matching hypothesis both for WIF (Hypothesis 2a) and for FIW (Hypothesis $2 b)$.

\section{Moderator Analyses}

Because many values for single variables were based on few studies, we decided to conduct a mod- erator analyses only for the three general categories, thereby ensuring enough power for the moderator analyses. As shown in Tables 2 and 3, homogeneity was given for only one of the six associations, that is, for the association between WIF and family-related outcomes. Nevertheless, moderator analyses were conducted for all associations between WIF/FIW and outcomes. We tested for the moderating effect of hours at work and parenthood on the relationship between work-family conflict and different outcomes. Results are displayed in Table 4.

No moderating effects were found for parenthood. Hours at work significantly moderated two associations (WIF with family-related outcomes, FIW with domain-unspecific outcomes), indicating that the relationships were stronger in samples in which participants had above-average working hours. Furthermore, with the exception of one association (which was zero), all other associations between the effect sizes and hours at work point in the same positive direction.

Thus, Hypothesis $3 b$ (parenthood) was not confirmed. There was some support for Hypothesis $3 \mathrm{a}$ (hours at work); however, further research is needed.

\section{Discussion}

The present meta-analysis not only confirms a number of results of previous studies, but it also fills

Table 4

Standardized Regression Coefficients Between Effect Sizes and Moderator Variables for Work Interference With Family (WIF) and Family Interference With Work (FIW)

\begin{tabular}{lcc}
\hline \multicolumn{1}{c}{ Relationship } & $\%$ Parenthood & $\begin{array}{c}\text { Mean hours } \\
\text { at work/week }\end{array}$ \\
\hline $\begin{array}{l}\text { WIF: Domain-unspecific } \\
\text { outcome }\end{array}$ & $.20(62 / 34)$ & $.00(30 / 18)$ \\
$\begin{array}{l}\text { WIF: Work-related } \\
\text { outcome }\end{array}$ & $-.15(108 / 53)$ & $.15(66 / 24)$ \\
$\begin{array}{l}\text { WIF: Family-related } \\
\text { outcome }\end{array}$ & $-.17(31 / 24)$ & $.44^{* * *}(19 / 13)$ \\
$\begin{array}{l}\text { FIW: Domain-unspecific } \\
\text { outcome }\end{array}$ & $-.15(37 / 25)$ & $.66^{* *}(16 / 11)$ \\
$\begin{array}{l}\text { FIW: Work-related } \\
\text { outcome }\end{array}$ & $.02(83 / 42)$ & $.09(48 / 18)$ \\
$\begin{array}{l}\text { FIW: Family-related } \\
\text { outcome }\end{array}$ & $.14(22 / 19)$ & $.04(11 / 9)$ \\
\hline
\end{tabular}

Note. The first number in parentheses is the number of effect sizes on Level 1; the second number in parentheses is the number of studies, which provided the moderator information on Level $2(=k / N)$.

${ }^{*} p<.05$ (two-tailed). ${ }^{* *} p<.01$ (two-tailed). 
existing gaps by investigating both directions of the conflict and their association with a large number of outcomes. These data, therefore, allow us to disentangle specific effects of WIF and FIW, and specifically help decide between two competing hypotheses, the cross-domain and matching hypotheses.

\section{Work-Family Conflict and Different Outcomes}

The results of the present meta-analysis mostly confirmed our assumptions about the relationship between work-family conflict and different outcomes. Both directions of work-family conflict were related to work-related outcomes, family-related outcomes, and domain-unspecific outcomes. The only nonsignificant relationship was found between FIW and family performance. Overall, most of the effect sizes were small to modest (Cohen, 1988).

Considering the number of studies about workfamily conflict, work-related outcomes were the variables most often studied, and this applies to both directions of the conflict. A reason for this dominance of work-related outcomes may be seen in the fact that work-family conflict is mainly studied in the field of work and organizational psychology. Therefore, work-related aspects are in the foreground of interest.

Among these work-related outcomes, work satisfaction was the most popular indicator studied. Work satisfaction is related to many indicators of mental health as well as to physical health (Faragher, Cass, \& Cooper, 2005); it can be regarded as a central aspect of an individual's well-being (Warr, 2007). Family satisfaction may be seen as the counterpart of work satisfaction; it was the most frequently studied variable among the family-related outcomes, with regard to WIF as well as FIW. It therefore is not surprising that two of the few previous meta-analyses focused solely on the relationship between WIF/FIW and job, family, or life satisfaction (Ford et al., 2007; Kossek \& Ozeki, 1998).

For both WIF and FIW, we found the strongest association with domain-unspecific outcomes. Allen et al. (2000) also found the strongest relationship between WIF and stress-related well-being. Of the domain-unspecific outcomes other than measures of satisfaction, psychological strain and somatic/ physical symptoms were most frequently analyzed in relation to WIF, and depression in relation with FIW.

In sum, the majority of studies assessed workrelated outcomes, both in relationship with WIF and FIW. However, the strongest relationships between
WIF and FIW were shown with domain-unspecific outcomes. This allows us to conclude that future research on work-family conflict should include not only domain-specific outcomes but also domainunspecific outcomes (e.g., general well-being indicators).

\section{Cross-Domain Versus Matching Hypothesis}

Differentiating between both directions of workfamily conflict is important if different correlation patterns exist for WIF and FIW. Our results showed this to be the case. WIF was more strongly associated with work-related than with family-related outcomes, and FIW was more strongly associated with familyrelated than with work-related outcomes, which confirms the matching hypothesis.

It seems that WIF not only is created mainly by work, rather than family, stressors (Byron, 2005; Ford et al., 2007), but also has its consequences primarily in the work, rather than the family, environment. Similarly, FIW not only is created mainly by family, rather than work, stressors, but also seems to have its consequences mainly in the family, rather than the work, domain. This does not mean that the cross-domain relationship can be neglected. WIF/ FIW is associated with both work- and family-related outcomes, but the relationships are stronger with outcomes in the matching, as compared with crossdomain, outcomes. An effect of the cross-domain relationship is shown in our results as well as in the results from other meta-analyses (Ford et al., 2007). However, because no causality can be inferred from these mostly cross-sectional results, different explanations may be considered for this phenomenon. We focus our discussion on the relationship between WIF and work-related outcomes; analogous explanations can be given for the relationship between FIW and family-related outcomes.

The first explanation is that work-related outcomes may be seen as an antecedent for WIF rather than as a consequence of WIF. This would explain the results as follows: Work stressors influence one's workrelated well-being. A negative work-related wellbeing in turn creates WIF, which influences one's family-related well-being. Following this explanation, our results would show that WIF is more strongly related to its antecedents than to its consequences. This consideration follows a model based on Frone et al. (1992a) and further developed by Frone, Yardley, and Markel (1997). In this model, two feedback loops have been integrated, so that domain-specific outcomes (e.g., family-related well- 
being) are related to same-domain antecedents (e.g., family-related antecedents). Therefore, according to our considerations and to the model of Frone et al. (1997), a given variable might be a direct outcome of FIW but also a direct antecedent of WFC. The investigation of such feedback loops would create a greater understanding of work-family processes. However, only longitudinal studies can answer the question of causality. Therefore, it would be important for further research to investigate such workfamily processes with longitudinal designs.

Second, a stressful work environment may have an impact on an individual's well-being by affecting one's work-related well-being directly and simultaneously creating WIF. WIF, in turn, influences both one's family-related well-being and one's workrelated well-being. The idea behind this explanation is that the influence of the work and the family domain is reciprocal and should be seen as a spiral rather than a unidirectional process (Demerouti, Bakker, \& Bulters, 2004). This would also explain the relationship between WIF and FIW (MesmerMagnus \& Viswesvaran, 2005) because an impaired family-related well-being may additionally promote FIW conflicts. Nevertheless, it is important to differentiate between WIF and FIW, which does not mean that one direction of interrole conflict cannot create or influence the other direction.

The strongest relationship with both directions of the interrole conflict was found for domainunspecific outcomes, which was also shown by Kossek and Ozeki (1998) with regard to life satisfaction. We explain this effect by supposing that both domain-specific outcomes have an influence on domain-unspecific outcomes (e.g., Aryee et al., 1999; Bedeian, Burke, \& Moffett, 1988; Frone et al., 1992a). Kelloway and Barling (1991) tested this assumption and found that job characteristics had an indirect influence on context-free mental health, which was mediated through job-related well-being (cf. Warr, 2007). According to additive models of well-being, the perceived overall quality of life may be seen as a "distal variable" that is associated with the (more proximal) quality of life in each life domain (Frone et al., 1992a). Therefore, the domainspecific well-being indicators additively influence general well-being indicators.

It is possible, however, that the strong association between (domain-unspecific) stress and WIF may be explained by work stress being confounded with the general measures of stress. This interpretation is very plausible, given that unspecific stress and workrelated stress are correlated (Warr, 2007). Further- more, Kelloway and Barling (1991) demonstrated that the association of work-related variables with general well-being was fully mediated by workrelated well-being. On the other hand, the correlations between work-related and domain-unspecific, or "context-free," indicators reviewed by Warr (2007) were substantial but not so large as to suggest the two are substitutable for one another. Furthermore, Grebner, Semmer, and Elfering (2005) found that work-related stress symptoms and domainunspecific stress symptoms were in part predicted by different variables, suggesting that each also contains specific variance. Taken together, such findings indicate that a confound with work-related stress does exist; with the exception of Kelloway and Barling (1991), however, they do not suggest that the relationship between WIF and (general) stress is due exclusively to this confound. Whatever the interpretation, our results clearly show that it is important to distinguish between WIF and FIW as different correlation patterns emerged for the two directions.

\section{Moderators}

As argued in the introduction, there are theoretical reasons to hypothesize moderator effects. indeed, the need for analyzing moderator effects is indicated by the heterogeneity of our results, which is in line with the results of other meta-analyses (e.g., Allen et al., 2000). We tested for two moderators that plausibly could influence the relationship between workfamily conflict and its consequences: time spent at work and parenthood.

Time spent at work. Our work-related moderator was time spent at work. We hypothesized that the number of hours spent at work should enhance the negative effect of work-family conflict on different outcomes. A high number of hours at work should reduce the possibility of restoring one's resources, for example, by investing less time in one's social network (Viswesvaran, Sanchez, \& Fisher, 1999). Moreover, Sonnentag and Bayer's (2005) study indicated that long hours at work have a negative effect on psychological detachment from work, which is an important resource for recovery, which, in turn, is important for well-being. Therefore, long hours at work should enhance the negative effect of workfamily conflict on well-being.

We found two moderating effects of time spent at work, and both were in the expected direction. Furthermore, except for one zero effect, all signs were in the expected direction. Therefore, it seems that the role of hours worked is not restricted to a main effect 
on WIF (which has been shown in a number of studies; e.g., Jacobshagen et al., 2005; Major et al., 2002; van Rijswijk, Bekker, Rutte, \& Croon, 2004). Note, however, that hours worked is a very crude measure with regard to the processes involved. A number of factors may qualify this relationship, such as the number of hours spent at work versus the quality of work (Greenhaus \& Parasuraman, 1999) or the question of whether overtime is self-chosen or demanded (cf. Tucker \& Rutherford, 2005). Typically, measures of overload are better predictors of WIF than are the mere number of hours (Byron, 2005; Greenhaus \& Parasuraman, 1999; Jacobshagen et al., 2005). This might explain why only two of six moderations became significant.

Parenthood. We hypothesized that parenthood would enhance the relationship between work-family conflict and different outcomes because parenthoodrelated activities, such as child-care responsibilities, are a demanding aspect of family life. But results showed no effect. Having children or not is a very crude measure of care responsibilities. Other factors might be better indicators of the demanding aspect of child care, for instance, the number and age of the children or single parenthood. Unfortunately, most of the studies did not provide this information. Those that provided it did so in a way that could not be used meta-analytically. Thus, some articles reported the percentage of participants with children below 3 years of age, others the percentage of participants with children living at home and going to school, or just the percentage of participants with children but without further description.

Limitation of moderator analyses. First, given the heterogeneity of effect sizes, and the fact that only one moderator (hours at work) yielded significant effects, it seems likely that other moderators may play a role. Possible candidates are the economic background of the sample, as better economic resources may help ward off some of the consequences of WIF/FIW (cf. Hobfoll, 1989). Unfortunately, studies often do not report sufficient information with regard to the economic background of their sample. Similarly, information about other possible moderators, such as support, control, or centrality of life domains, often was not sufficient. With almost all studies coming from the United States, we could not analyze the origin of the sample as a moderator variable.

Second, the limited amount of significant moderator effects may be due to our rather generic categories of work-related and family-related outcomes. Unfortunately, the specific outcome categories could not be tested for moderator effects in a reliable way. Given the small number of effect sizes per category and moderator, power was not sufficient.

However, the hypothesized mechanisms behind a moderator effect are at an individual level, but moderation tests in meta-analyses are on a study level. Therefore, moderating effects or, as in our case, the lack thereof, should be interpreted with caution because a moderating effect that holds for one level does not necessarily hold for the other, implying the danger of an ecological fallacy.

\section{Practical Implications}

The results of this meta-analysis have a number of practical implications. Our results confirm the association of work-family conflict with a large number of indicators of well-being. Organizations and supervisors who are interested in healthy employees should therefore include attempts to minimize conflicts between work and family life in their considerations. Moreover, a conflict originating in the work environment (i.e., WIF) is related particularly strongly to work-related outcomes, and these include not only well-being but also work performance and withdrawal tendencies. Thus, organizations should be motivated to create a family-friendly work environment.

Overall, the results show that the importance avoiding work-family conflict goes beyond individual well-being but includes other variables that are of direct importance for organizational effectiveness. Strategies that foster a family-friendly work environment are, therefore, likely to benefit both the organization and the employee. At the same time, such benefits are not automatically implied by official family-friendly policies unless these are perceived by employees as signaling a family-friendly climate at work (Allen, 2001). The behavior of supervisors is especially important in this respect, so they should be encouraged and supported in their attempts to convey a family-friendly climate (Hammer, Kossek, Yragui, Bodner, \& Hanson, 2009).

\section{Outlook and Conclusion}

The interface between work and family has received broad attention during the past 20 years. Research interest in this topic is associated with changes in societal structure, especially the rising number of dual-earner couples with children. This interest in the challenge of combining work and family is not likely to fade in light of foreseeable changes in the family 
as well as the work environment for a number of reasons.

Regarding families, the number of dual-earner couples with children is not likely to decline. Therefore, more and more individuals have to combine work and family responsibilities. Second, child care is no longer exclusively a women's topic because fathers' involvement with children is growing (Halpern, 2005). Third, the number of single parents is rather high, which might have an impact on combining work and family duties (Duxbury, Higgins, \& Lee, 1994). Fourth, external child care will likely become more common and even perhaps be taken for granted, which allows parents more control over their family duties and possibly facilitates combining work and family responsibilities (Voydanoff, 2005c).

The work environment is also likely to change. Therefore, a number of reasons for the interest in the topic of work-family come from the working environment. First, a European survey shows that parttime work has increased drastically in Europe in the past 15 years (European Foundation for the Improvement of Living and Work Conditions, 2007), and working part time may be a strategy to prevent workfamily conflict (Higgins et al., 2000). We expect this trend to continue in the next years. A second point of interest is the phenomenon of the working poor because poverty has especially strong effects on families with small children. On the one hand, these families cannot afford to pay for external child care, which may reduce family-related resources (Voydanoff, 2005c). On the other hand, economic hardship seems to decrease social support and increase social undermining among couples, which is related to depression and relationship satisfaction (Vinokur, Price, \& Caplan, 1996). A third possible change concerns commuting from work to home. The duration of commuting is rising because more regional flexibility is required from working individuals. This may make external child care more difficult, especially because grandparents no longer live nearby.

All these reasons (and certainly many more) suggest that combining work and family will continue to constitute a challenge in the coming decades. Therefore, it will be important to further analyze workfamily conflict and its antecedents as well as its consequences.

To conclude, the present meta-analysis demonstrates that work-family conflict affects well-being and behavior not only in general, but also with respect to family and working life. However, it is important to stress that combining these two life domains can have a positive effect as well. It has repeatedly been demonstrated that living multiple life domains has a positive effect on individuals' wellbeing and health (Barnett \& Hyde, 2001; Kotler \& Wingard, 1989; Ross \& Mirowsky, 1995). Furthermore, positive reciprocal influences of work and family (work-family enrichment or facilitation) have been demonstrated in a number of studies (see Greenhaus \& Powell, 2006). Thus, it is important to gain a better understanding of the dynamics of this process, both in terms of negative and positive aspects. This should aid the development of better measures of prevention and intervention.

\section{References}

References marked with an asterisk indicate studies included in the meta-analysis.

*Adams, G. A., Durand, D. B., Burrell, L., Teitelbaum, J. M., Pehrson, K. L., \& Hawkins, J. P. (2005). Direct and indirect effects of operations tempo on outcomes for soldiers and spouses. Military Psychology, 17, 229-246.

*Allen, T. D. (2001). Family-supportive work environments: The role of organizational perceptions. Journal of Vocational Behavior, 58, 414-435.

Allen, T. D., Herst, D. E. L., Bruck, C. S., \& Sutton, M. (2000). Consequences associated with work-to-family conflict: A review and agenda for future research. Journal of Occupational Health Psychology, 5, 278-308.

*Anderson, S. E., Coffey, B. S., \& Byerly, R. T. (2002). Formal organizational initiatives and informal workplace practices: Links to work-family conflict and job-related outcomes. Journal of Management, 28, 787-810.

*Aryee, S., Fields, D., \& Luk, V. (1999). A cross-cultural test of a model of the work-family interface. Journal of Management, 25, 491-511.

*Aryee, S., Srinivas, E. S., \& Tan, H. H. (2005). Rhythms of life: Antecedents and outcomes of work-family balance in employed parents. Journal of Applied Psychology, 90, 132-146.

*Aycan, Z., \& Eskin, M. (2005). Relative contributions of childcare, spousal support, and organizational support in reducing work-family conflict for men and women: The case of Turkey. Sex Roles, 53, 453-471.

*Bakker, A. B., \& Geurts, S. (2004). Toward a dual-process model of work-home interference. Work and Occupations, 31, 345-366.

Barnett, R. C. (1998). Toward a review and reconceptualization of the work/family literature. Genetic, Social, and General Psychology Monographs, 124, 125-182.

Barnett, R. C., \& Hyde, J. S. (2001). Women, men, work, and family. American Psychologist, 56, 781-796.

*Batt, R., \& Valcour, P. M. (2003). Human resources practices as predictors of work-family outcomes and employee turnover. Industrial Relations, 42, 189-220.

Bedeian, A. T., Burke, B. G., \& Moffett, R. G. (1988). Outcomes of work-family conflict among married male and female professionals. Journal of Management, 14, 475-491.

*Behson, S. J. (2002a). Coping with family-to-work conflict: The role of informal work accommodations to fam- 
ily. Journal of Occupational Health Psychology, 7, 324341.

*Behson, S. J. (2002b). Which dominates? The relative importance of work-family organizational support and general organizational context on employee outcomes. Journal of Vocational Behavior, 61, 53-72.

*Behson, S. J. (2005). The relative contribution of formal and informal organizational work-family support. Journal of Vocational Behavior, 66, 487-500.

Bellavia, F. M., \& Frone, M. R. (2005). Work-family conflict. In J. Barling, E. K. Kelloway, \& M. R. Frone (Eds.), Handbook of work stress (pp. 113-147). London: Sage.

*Bernas, K. H., \& Major, D. A. (2000). Contributors to stress resistance: Testing a model of women's workfamily conflict. Psychology of Women Quarterly, 24, $170-178$.

*Beutell, N. J., \& Wittig-Berman, U. (1999). Predictors of work-family conflict and satisfaction with family, job, career, and life. Psychological Reports, 85, 893-903.

*Bhuian, S. N., Menguc, B., \& Borsboom, R. (2003). Stressors and job outcomes in sales: A triphasic model versus a linear-quadratic-interactive model. Journal of Business Research, 58, 141-150.

*Boles, J. S., Howard, W. G., \& Donofrio, H. H. (2001). An investigation into the inter-relationships of work-family conflict, family-work conflict and work satisfaction. Journal of Managerial Issues, 13, 376-390.

*Boles, J. S., Wood, J. A., \& Johnson, J. (2003). Interrelationships of role conflict, role ambiguity, and workfamily conflict with different facets of job satisfaction and the moderating effects of gender. Journal of Personal Selling \& Sales Management, 23, 99-113.

Bortz, J. (1993). Statistik für Sozialwissenschaftler [Statistics for social sciences]. Berlin: Springer.

*Boyar, S. L., Maertz, C. P., \& Pearson, A. W. (2005). The effects of work-family conflict and family-work conflict on nonattendance behaviors. Journal of Business Research, 58, 919-925.

*Boyar, S. L., Maertz, C. P., Pearson, A. W., \& Keough, S. (2003). Work-family conflict: A model of linkages between work and family domain variables and turnover intentions. Journal of Managerial Issues, 15, 175-190.

*Britt, T. W., \& Dawson, C. R. (2005). Predicting workfamily conflict from workload, job attitudes, group attributes, and health: A longitudinal study. Military Psychology, 17, 203-227.

* Brough, P. (2005). A comparative investigation of the predictors of work-related psychological well-being within police, fire, and ambulance workers. New Zealand Journal of Psychology, 34, 127-134.

*Brough, P., \& Kelling, A. (2002). Women, work and well-being: The influence of work-family and familywork conflict. New Zealand Journal of Psychology, 31, 29-38.

*Brough, P., O’Driscoll, M. P., \& Kalliath, T. J. (2005). The ability of "family friendly" organizational resources to predict work-family conflict and job and family satisfaction. Stress and Health, 21, 223-234.

*Bruck, C. S., Allen, T. D., \& Spector, P. E. (2002). The relation between work-family conflict and job satisfaction: A finer-grained analysis. Journal of Vocational Behavior, 60, 336-353.

Bruk-Lee, V., \& Spector, P. E. (2006). The social stressors- counterproductive work behaviors link: Are conflicts with supervisors and coworkers the same? Journal of Occupational Health Psychology, 11, 145-156.

Byron, K. (2005). A meta-analytic review of work-family conflict and its antecedents. Journal of Vocational Behavior, 67, 169-198.

*Cardenas, R. A., Major, D. A., \& Bernas, K. H. (2004). Exploring work and family distractions: Antecedents and outcomes. International Journal of Stress Management, 11, 346-365.

*Carlson, D. S., \& Kacmar, K. M. (2000). Work-family conflict in the organization: Do life role values make a difference? Journal of Management, 26, 1031-1054.

Carlson, D. S., Kacmar, K. M., \& Williams, L. J. (2000). Construction and initial validation of a multidimensional measure of work-family conflict. Journal of Vocational Behavior, 56, 249-276.

*Carmeli, A. (2003). The relationship between emotional intelligence and work attitudes, behavior and outcomes: An examination among senior managers. Journal of Managerial Psychology, 18, 788-813.

Casper, W. J., Eby, L. T., Bordeaux, C., Lockwood, A., \& Lambert, D. (2007). A review of research methods in IO/OB work-family research. Journal of Applied Psychology, 92, 28-43.

*Casper, W. J., Martin, J. A., Buffardi, L. C., \& Erdwins, C. J. (2002). Work-family conflict, perceived organizational support, and organizational commitment among employed mothers. Journal of Occupational Health Psychology, 7, 99-108.

*Chesley, N. (2005). Blurring boundaries? Linking technology use, spillover, individual distress, and family satisfaction. Journal of Marriage and Family, 67, 1237-1248.

Cohen, J. (1988). Statistical power analysis for the behavioral sciences. New York: Academic Press.

*Demerouti, E., Bakker, A. B., \& Bulters, A. J. (2004). The loss spiral of work pressure, work-home interference and exhaustion: Reciprocal relations in a three-wave study. Journal of Vocational Behavior, 64, 131-149.

*Demerouti, E., Bakker, A. B., \& Schaufeli, W. B. (2005). Spillover and crossover of exhaustion and life satisfaction among dual-earner parents. Journal of Vocational Behavior, 67, 266-289.

*Demerouti, E., \& Geurts, S. (2004). Towards a typology of work-home interaction. Community, Work \& Family, 7, 285-309.

*Demerouti, E., Geurts, S., Bakker, A., \& Euwema, M. (2004). The impact of shiftwork on work-home conflict, job attitudes and health. Ergonomics, 47, 987-1002.

Diener, E., \& Diener, M. (1995). Cross-cultural correlates of life satisfaction and self-esteem. Journal of Personality and Social Psychology, 68, 653-663.

Duxbury, L., Higgins, C., \& Lee, C. (1994). Work-family conflict: A comparison by gender, family type, and perceived control. Journal of Family Issues, 15, 449-466.

Eagle, B. W., Miles, E. W., \& Icenogle, M. L. (1997). Interrole conflicts and the permeability of work and family domains: Are there gender differences? Journal of Vocational Behavior, 50, 168-184.

Eby, L. T., Casper, W. J., Lockwood, A., Bordeaux, C., \& Brinley, A. (2005). Work and family research in IO/OB: Content analysis and review of the literature (19802002). Journal of Vocational Behavior, 66, 124-197.

European Foundation for the Improvement of Living and 
Work Conditions. (2007). Part-time work in European companies. Luxembourg: Office for Official Publications of the European Communities.

Faragher, E. B., Cass, M., \& Cooper, C. L. (2005). The relationship between job satisfaction and health: A metaanalysis. Occupational Environmental Medicine, 62, $105-112$.

Ford, M. T., Heinen, B. A., \& Langkamer, K. L. (2007). Work and family satisfaction and conflict: A metaanalysis of cross-domain relations. Journal of Applied Psychology, 92, 57-80.

Fox, M. L., \& Dwyer, D. J. (1999). An investigation of the effects of time and involvement in the relationships between stressors and work-family conflict. Journal of Occupational Health Psychology, 4, 164-174.

*Frone, M. R. (2000). Work-family conflict and employee psychiatric disorders: The National Comorbidity Survey. Journal of Applied Psychology, 85, 888-895.

Frone, M. R. (2003). Work-family balance. In J. Campbell Quick \& L. E. Tetrick (Eds.), Handbook of occupational health psychology (pp. 143-162). Washington, DC: American Psychological Association.

Frone, M. R., Russell, M., \& Cooper, M. L. (1992a). Antecedents and outcomes of work-family conflict: Testing a model of the work-family interface. Journal of Applied Psychology, 77, 65-78.

Frone, M. R., Russell, M., \& Cooper, M. L. (1992b). Prevalence of work-family conflict: Are work and family boundaries asymmetrically permeable? Journal of Organizational Behavior, 13, 723-729.

Frone, M. R., Yardley, J. K., \& Markel, K. S. (1997). Developing and testing an integrative model of the workfamily interface. Journal of Vocational Behavior, 50, 145-167.

*Frye, N. K., \& Breaugh, J. A. (2004). Family-friendly policies, supervisor support, work-family conflict, family-work conflict, and satisfaction: A test of a conceptual model. Journal of Business and Psychology, 19, 197220.

Geurts, S. A. E., \& Demerouti, E. (2003). Work/non-work interface: A review of theories and findings. In M. J. Schabracq, J. A. M. Winnubst, \& C. L. Cooper (Eds.), Handbook of work and health psychology (pp. 279-312). Chichester, England: Wiley.

*Geurts, S. A. E., Kompier, M. A. J., Roxburgh, S., \& Houtman, I. L. D. (2003). Does work-home interference mediate the relationship between workload and wellbeing? Journal of Vocational Behavior, 63, 532-559.

*Geurts, S. A. E., Rutte, C., \& Peeters, M. (1999). Antecedents and consequences of work-home interference among medical residents. Social Science \& Medicine, 48, $1135-1148$.

*Golden, T. D. (2006). The role of relationships in understanding telecommuter satisfaction. Journal of Organizational Behavior, 27, 319-340.

*Grandey, A. A., Cordeiro, B. L., \& Crouter, A. C. (2005). A longitudinal and multi-source test of the work-family conflict and job satisfaction relationship. Journal of Occupational and Organizational Psychology, 78, 305-323.

*Grant-Vallone, E. J., \& Ensher, E. A. (2001). An examination of work and personal life conflict, organizational support, and employee health among international expatriates. International Journal of Intercultural Relations, 25, 261-278.
Grebner, S., Semmer, N. K., \& Elfering, A. (2005). Working conditions and three types of well-being: A longitudinal study with self-report and rating data. Journal of Occupational Health Psychology, 10, 31-43.

Greenhaus, J. H., \& Beutell, N. J. (1985). Sources of conflict between work and family roles. Academy of Management Review, 10, 76-88.

*Greenhaus, J. H., Collins, K. M., \& Shaw, J. D. (2003). The relation between work-family balance and quality of life. Journal of Vocational Behavior, 63, 510-531.

Greenhaus, J. H., \& Parasuraman, S. (1999). Research on work, family, and gender: Current status and future directions. In G. N. Powell (Ed.), Handbook of gender and work (pp. 391-412). Thousand Oaks, CA: Sage.

*Greenhaus, J. H., Parasuraman, S., \& Collins, K. M. (2001). Career involvement and family involvement as moderators of relationships between work-family conflict and withdrawal from a profession. Journal of Occupational Health Psychology, 6, 91-100.

Greenhaus, J. H., \& Powell, G. N. (2006). When work and family are allies: A theory of work-family enrichment. Academy of Management Review, 31, 72-92.

*Griffin, M. L. (2006). Gender and stress: A comparative assessment of sources of stress among correctional officers. Journal of Contemporary Criminal Justice, 22, $4-25$.

Grzywacz, J. G., \& Bass, B. L. (2003). Work, family, and mental health: Testing different models of work-family fit. Journal of Marriage and Family, 65, 248-262.

*Haar, J. M. (2004). Work-family conflict and turnover intention: Exploring the moderation effects of perceived work-family support. New Zealand Journal of Psychology, 33, 35-39.

Halpern, D. F. (2005). Psychology at the intersection of work and family: Recommendations for employers, working families, and policymakers. American Psychologist, 60, 397-409.

*Hammer, L. B., Bauer, T. N., \& Grandey, A. A. (2003). Work-family conflict and work-related withdrawal behaviors. Journal of Business and Psychology, 17, 419436.

*Hammer, L. B., Cullen, J. C., Neal, M. B., Sinclair, R. R., \& Shafiro, M. V. (2005). The longitudinal effects of work-family conflict and positive spillover on depressive symptoms among dual-earner couples. Journal of Occupational Health Psychology, 10, 138-154.

Hammer, L. B., Kossek, E. E., Yragui, N. L., Bodner, T. E., \& Hanson, G. C. (2009). Development and validation of a multidimensional measure of family supportive supervisor behaviors (FSSB). Journal of Management, 35, 837-856.

*Hammer, T. H., Saksvik, P. O., Nytro, K., Torvatn, H., \& Bayazit, M. (2004). Expanding the psychological work environment: Workplace norms and work-family conflict as correlates of stress and health. Journal of Occupational Health Psychology, 9, 83-97.

Higgins, C., Duxbury, L., \& Johnson, K. L. (2000). Parttime work for women: Does it really help balance work and family? Human Resource Management, 39, 17-32.

Hobfoll, S. E. (1989). Conservation of resources: A new attempt at conceptualizing stress. American Psychologist, 44, 513-524.

*Hogan, N. L., Lambert, E. G., Jenkins, M., \& Wambold, S. (2006). The impact of occupational stressors on correc- 
tional staff organizational commitment. Journal of Contemporary Criminal Justice, 22, 44-62.

*Hom, P. W., \& Kinicki, A. J. (2001). Toward a greater understanding of how dissatisfaction drives employee turnover. Academy of Management Journal, 44, 975987.

*Huang, Y. H., Hammer, L. B., Neal, M. B., \& Perrin, N. A. (2004). The relationship between work-to-family conflict and family-to-work conflict: A longitudinal study. Journal of Family and Economic Issues, 25, 79-100.

Hunter, J. E., \& Schmidt, F. L. (1990). Methods of metaanalysis: Correcting error and bias in research findings. Thousand Oaks, CA: Sage.

Hunter, J. E., \& Schmidt, F. L. (2000). Fixed effects vs. random effects meta-analysis models: Implications for cumulative research knowledge. International Journal of Selection and Assessment, 8, 275-292.

Hunter, J. E., Schmidt, F. L., \& Jackson, G. B. (1982). Meta-analysis. Cumulating research findings across studies. Thousand Oaks, CA: Sage.

Ioannidis, J. P. A., \& Lau, J. (2001). Evolution of treatment effects over time: Empirical insight from recursive cumulative meta-analyses. Proceedings of the National Academy of Sciences, USA, 98, 831-836.

Jacobshagen, N., Amstad, F. T., Semmer, N. K., \& Kuster, M. (2005). Work-Family-Balance im Topmanagment: Konflikt zwischen Arbeit und Familie als Mediator der Beziehung zwischen Stressoren und Befinden. [Workfamily balance in the top management: Work-family conflict as mediator of the relationship between stressors and well-being]. Zeitschrift für Arbeits- und Organisationspsychologie, 49, 208-219.

*Janssen, P. P. M., Peeters, M. C. W., Jonge, J., Houkes, I., \& Tummers, G. E. R. (2004). Specific relationships between job demands, job resources and psychological outcomes and the mediating role of negative work-home interference. Journal of Vocational Behavior, 65, 411429.

*Jex, S. M., \& Elacqua, T. C. (1999). Time management as a moderator of relations between stressors and employee strain. Work \& Stress, 13, 182-191.

*Judge, T. A., \& Colquitt, J. A. (2004). Organizational justice and stress: The mediating role of work-family conflict. Journal of Applied Psychology, 89, 395-404.

Kahn, R. L., \& Byosiere, P. (1992). Stress in organizations. In M. D. Dunnette \& L. M. Hough (Eds.), Handbook of industrial and organizational psychology (Vol. 3, pp. 571-650). Palo Alto, CA: Consulting Psychology Press.

Kahn, R. L., Wolfe, D., Quinn, R., Snoek, J., \& Rosenthal, R. (1964). Organizational stress: Studies in role conflict and ambiguity. New York: Wiley.

Kelloway, E. K., \& Barling, J. (1991). Job characteristics, role stress and mental health. Journal of Occupational Psychology, 64, 291-304.

*Kelloway, E. K., Gottlieb, B. H., \& Barham, L. (1999). The source, nature, and direction of work and family conflict: A longitudinal investigation. Journal of Occupational Health Psychology, 4, 337-346.

*Kinnunen, U., Geurts, S., \& Mauno, S. (2004). Work-tofamily conflict and its relationship with satisfaction and well-being: A one-year longitudinal study on gender differences. Work \& Stress, 18, 1-22.

*Kinnunen, U., Vermulst, A., Gerris, J., \& Mäkikangas, A. (2003). Work-family conflict and its relations to well- being: The role of personality as a moderating factor. Personality and Individual Differences, 35, 1669-1683.

*Kirchmeyer, C., \& Cohen, A. (1999). Different strategies for managing the work/non-work interface: A test for unique pathways to work outcomes. Work \& Stress, 13, 59-73.

Koslowsky, M., \& Sagie, A. (1993). On the efficacy of credibility intervals as indicators of moderator effects in meta-analytic research. Journal of Organizational Behavior, 14, 695-699.

*Kossek, E. E., Colquitt, J. A., \& Noe, R. A. (2001). Caregiving decisions, well-being, and performance: The effects of place and provider as a function of dependent type and work-family climates. Academy of Management Journal, 44, 29-44.

*Kossek, E. E., Lautsch, B. A., \& Eaton, S. C. (2006). Telecommuting, control, and boundary management: Correlates of policy use and practice, job control, and work-family effectiveness. Journal of Vocational Behavior, 68, 347-367.

Kossek, E. E., \& Ozeki, C. (1998). Work-family conflict, policies, and the job-life satisfaction relationship: A review and directions for organizational behavior-human resources research. Journal of Applied Psychology, 83, $139-149$.

Kossek, E. E., \& Ozeki, C. (1999). Bridging the workfamily policy and productivity gap: A literature review. Community, Work \& Family, 2, 7-32.

Kotler, P., \& Wingard, D. L. (1989). The effect of occupational, marital and parental roles on mortality: The Alameda County Study. American Journal of Public Health, 79, 607-612.

*Kovner, C., Brewer, C., Wu, Y. W., Cheng, Y., \& Suzuki, M. (2006). Factors associated with work satisfaction of registered nurses. Journal of Nursing Scholarship, 38, 71-79.

*Lambert, E. G., Hogan, N. L., \& Barton, S. M. (2002). The impact of work-family conflict on correctional staff job satisfaction: An exploratory study. American Journal of Criminal Justice, 27, 35-52.

*Lapierre, L. M., \& Allen, T. D. (2006). Work-supportive family, family-supportive supervision, use of organizational benefits, and problem-focused coping: Implications for work-family conflict and employee well-being. Journal of Occupational Health Psychology, 11, 169181.

Lipsey, M. W., \& Wilson, D. B. (2001). Practical metaanalysis. Thousand Oaks, CA: Sage.

Livingston, B., \& Judge, T. A. (2008). Emotional response to work-family conflict: An examination of gender role orientation. Journal of Applied Psychology, 93, 207-216.

Lott, B. (1988). Separate spheres revisited. Contemporary Social Psychology, 13, 55-62.

Luk, D. M., \& Shaffer, M. A. (2005). Work and family domain stressors and support: Within- and cross-domain influences on work-family conflict. Journal of Occupational and Organizational Psychology, 78, 489-508.

*Major, V. S., Klein, K. J., \& Ehrhart, M. G. (2002). Work time, work interference with family, and psychological distress. Journal of Applied Psychology, 87, 427-436.

*Martins, L. L., Eddleston, K. A., \& Veiga, J. F. (2002). Moderators of the relationship between work-family conflict and career satisfaction. Academy of Management Journal, 45, 399-409. 
*Matthews, R. A., Del Priore, R. E., Acitelli, L. K., \& Barnes-Farrell, J. L. (2006). Work-to-relationship conflict: Crossover effects in dual-earner couples. Journal of Occupational Health Psychology, 11, 228-240.

*Mauno, S., \& Kinnunen, U. (1999). The effects of job stressors on marital satisfaction in Finnish dual-earner couples. Journal of Organizational Behavior, 20, 879895.

*Mauno, S., Kinnunen, U., \& Pyykkö, M. (2005). Does work-family conflict mediate the relationship between work-family culture and self-reported distress? Evidence from five Finnish organizations. Journal of Occupational and Organizational Psychology, 78, 509-530.

McDaniel, M. A., Hirsh, H. R., Schmidt, F. L., Raju, N. S., \& Hunter, J. E. (1986). Interpreting the results of metaanalytic research: A comment on Schmitt, Gooding, Noe, and Kursch (1984). Personnel Psychology, 39, 141-148.

*McElwain, A. K., Korabik, K., \& Rosin, H. M. (2005). An examination of gender differences in work-family conflict. Canadian Journal of Behavioral Science, 37, 283 298.

McMunn, A., Bartley, M., Hardy, R., \& Kuh, D. (2006). Life course social roles and women's health in mid-life: Causation or selection? Journal of Epidemiology and Community Health, 60, 484-489.

Mesmer-Magnus, J. R., \& Viswesvaran, C. (2005). Convergence between measures of work-to-family and familyto-work conflict: A meta-analytic examination. Journal of Vocational Behavior, 67, 215-232.

*Montgomery, A. J., Peeters, M. C. W., Schaufeli, W. B., \& den Ouden, M. (2003). Work-home interference among newspaper managers: Its relationship with burnout and engagement. Anxiety, Stress, and Coping, 16, 195-211.

Moore, J. E. (2000). Why is this happening? A causal attribution approach to work exhaustion consequences. Academy of Management Review, 5, 335-349.

Nelson, D. L., \& Burke, R. J. (Eds.). (2002). Gender, work stress, and health. Washington, DC: American Psychological Association.

*Netemeyer, R. G., Brashear-Alejandro, T., \& Boles, J. S. (2004). A cross-national model of job-related outcomes of work role and family role variables: A retail sales context. Journal of the Academy of Marketing Science, 32, 49-60.

*Netemeyer, R. G., Maxham, J. G., \& Pullig, C. (2005). Conflicts in the work-family interface: Links to job stress, customer service, employee performance, and customer purchase intent. Journal of Marketing, 69, 130143.

*Ngo, H. Y., \& Lui, S. Y. (1999). Gender differences in outcomes of work-family conflict: The case of Hong Kong managers. Sociological Focus, 32, 303-316.

*Noor, N. M. (2003). Work- and family-related variables, work-family conflict and women's well-being: Some observations. Community, Work \& Family, 6, 298-319.

*O'Driscoll, M. P., Brough, P., \& Kalliath, T. J. (2004). Work/family conflict, psychological well-being, satisfaction and social support: A longitudinal study in New Zealand. Equal Opportunities International, 23, 36-56.

*O'Driscoll, M. P., Poelmans, S., Spector, P. E., Kalliath, T., Allen, T. D., Cooper, C. L., \& Sanchez, J. I. (2003). Family-responsive interventions, perceived organizational and supervisor support, work-family conflict, and psychological strain. International Journal of Stress Management, 10, 326-344.

Parasuraman, S., \& Greenhaus, J. H. (2002). Toward reducing some critical gaps in work-family research. Human Resource Management Review, 12, 299-312.

*Peeters, M. C. W., de Jonge, J., Janssen, P. P. M., \& van der Linden, S. (2004). Work-home interference, job stressors, and employee health in a longitudinal perspective. International Journal of Stress Management, 11, 305-322.

*Peeters, M. C. W., Montgomery, A. J., Bakker, A. B., \& Schaufeli, W. B. (2005). Balancing work and home: How job and home demands are related to burnout. International Journal of Stress Management, 12, 43-61.

*Perrewé, P. L., Hochwarter, W. A., \& Kiewitz, C. (1999). Value attainment: An explanation for the negative effects of work-family conflict on life satisfaction. Journal of Occupational Health Psychology, 4, 318-326.

Pleck, J. H. (1977). The work-family role system. Social Problems, 24, 417-427.

*Rantanen, J., Pulkkinen, L., \& Kinnunen, U. (2005). The Big Five personality dimensions, work-family conflict, and psychological distress. Journal of Individual Differences, 26, 155-166.

Raudenbush, S. W., Bryk, A. S., Cheong, Y. F., \& Congdon, R. T. (2004). HLM 6: Hierarchical linear and nonlinear modeling. Lincolnwood, IL: SSI Scientific Software International.

*Reeve, C. L., Rogelberg, S. G., Spitzmüller, C., \& DiGiacomo, N. (2005). The caring-killing paradox: Euthanasia-related strain among animal-shelter workers. Journal of Applied Social Psychology, 35, 119-143.

Rosenthal, R. (1995). Writing meta-analytic reviews. Psychological Bulletin, 118, 183-192.

Ross, C. E., \& Mirowsky, J. (1995). Does employment affect health? Journal of Health and Social Behavior, 36, 230-243.

Rothbard, N. P., \& Edwards, J. R. (2003). Investment in work and family roles: A test of identity and utilitarian motives. Personnel Psychology, 56, 699-730.

Schwarzer, R. (1989). Meta-analysis programs by Ralf Schwarzer. Retrieved from http://web.fu-berlin.de/ gesund/gesu_engl/meta_e.htm

*Shaffer, M. A., Harrison, D. A., Gilley, K. M., \& Luk, D. M. (2001). Struggling for balance amid turbulence on international assignments: Work-family conflict, support and commitment. Journal of Management, 27, 99-121.

Sonnentag, S., \& Bayer, U.-V. (2005). Switching off mentally: Predictors and consequences of psychological detachment from work during off-job time. Journal of Occupational Health Psychology, 10, 393-414.

Spector, P. E. (1997). Job satisfaction. Thousand Oaks, CA: Sage.

*Stoeva, A. Z., Chiu, R. K., \& Greenhaus, J. H. (2002). Negative affectivity, role stress, and work-family conflict. Journal of Vocational Behavior, 60, 1-16.

Stoffelmayr, B. E., Dillavou, D., \& Hunter, J. E. (1983). Premorbid functioning and outcome in schizophrenia: A cumulative analysis. Journal of Consulting and Clinical Psychology, 51, 338-352.

*Sumer, H. C., \& Knight, P. A. (2001). How do people with different attachment styles balance work and family? A personality perspective on work-family linkage. Journal of Applied Psychology, 86, 653-663. 
*Swanson, V., \& Power, K. G. (1999). Stress, satisfaction and role conflict in dual-doctor partnerships. Community, Work \& Family, 2, 67-88.

*Tatman, A. T., Hovestadt, A. J., Yelsma, P., Fenell, D. L., \& Canfield, B. S. (2006). Work and family conflict: An often overlooked issue in couple and family therapy. Contemporary Family Therapy, 28, 39-51.

*Thompson, B. M., Brough, P. A., \& Schmidt, H. (2006). Supervisor and subordinate work-family values: Does similarity make a difference? International Journal of Stress Management, 13, 45-63.

*Thompson, C. A., Beauvais, L. L., \& Lyness, K. S. (1999). When work-family benefits are not enough: The influence of work-family culture on benefit utilization, organizational attachment, and work-family conflict. Journal of Vocational Behavior, 54, 392-415.

*Thompson, C. A., Jahn, E. W., Kopelman, R. E., \& Prottas, D. J. (2004). Perceived organizational family support: A longitudinal and multilevel analysis. Journal of Managerial Issues, 16, 545-565.

Tucker, P., \& Rutherford, C. (2005). Moderators of the relationship between long work hours and health. Journal of Occupational Health Psychology, 10, 465-476.

*Van Hooff, M., Geurts, S., Taris, T., Kompier, M., Dikkers, J., Houtman, I., \& Van den Heuvel, F. (2005). Disentangling the causal relationships between workhome interference and employee health. Scandinavian Journal of Work, Environment \& Health, 31, 15-29.

van Rijswijk, K., Bekker, M. H. J., Rutte, C. G., \& Croon, M. A. (2004). The relationships among part-time work, work-family interference, and well-being. Journal of Occupational Health Psychology, 9, 286-295.

*Vinokur, A. D., Pierce, P. F., \& Buck, C. L. (1999). Work-family conflicts of women in the Air Force: Their influence on mental health and functioning. Journal of Organizational Behavior, 20, 865-878.

Vinokur, A. D., Price, R. H., \& Caplan, R. D. (1996). Hard times and hurtful partners: How financial strain affects depression and relationship satisfaction of unemployed persons and their spouses. Journal of Personality and Social Psychology, 71, 166-179.

Viswesvaran, C., Sanchez, J. I., \& Fisher, J. (1999). The role of social support in the process of work stress: A meta-analysis. Journal of Vocational Behavior, 54, 314334.

Voydanoff, P. (2002). Linkages between the work-family interface and work, family and individual outcomes: An integrative model. Journal of Family Issues, 23, 138164.

*Voydanoff, P. (2004). Implications of work and community resources and demands for marital quality. Соттиnity, Work \& Family, 7, 311-325.

*Voydanoff, P. (2005a). Consequences of boundaryspanning demands and resources for work-to-family conflict and perceived stress. Journal of Occupational Health Psychology, 10, 491-503.

*Voydanoff, P. (2005b). Social integration, work-family conflict and facilitation, and job and marital quality. Journal of Marriage and Family, 67, 666-679.

Voydanoff, P. (2005c). Toward a conceptualization of perceived work-family fit and balance: A demands and resources approach. Journal of Marriage and Family, 67, $822-836$

*Voydanoff, P., \& Donnelly, B. W. (1999). Multiple roles and psychological distress: The intersection of the paid worker, spouse, and parent roles with the role of the adult child. Journal of Marriage and Family, 61, 725-738.

*Wallace, J. E. (2001). The benefits of mentoring for female lawyers. Journal of Vocational Behavior, 58, 366-391.

*Wang, P., Lawler, J. J., Walumbwa, F. O., \& Shi, K. (2004). Work-family conflict and job withdrawal intentions: The moderating effect of cultural differences. International Journal of Stress Management, 11, 392-412.

Warr, P. (2007). Work, happiness, and unhappiness. Mahwah, NJ: Erlbaum.

*Wayne, J. H., Musisca, N., \& Fleeson, W. (2004). Considering the role of personality in the work-family experience: Relationships of the Big Five to work-family conflict and facilitation. Journal of Vocational Behavior, 64, 108-130.

Weiner, B. (1985). An attributional theory of achievement motivation and emotion. Psychological Review, 92, 530543.

Whitener, E. M. (1990). Confusion of confidence intervals and credibility intervals in meta-analysis. Journal of Applied Psychology, 75, 315-321.

*Zickar, M. J., Gibby, R. E., \& Jenny, T. (2004). Job attitudes of workers with two jobs. Journal of Vocational Behavior, 64, 222-235.

Received July 3, 2009

Revision received June 26, 2010 Accepted September 6, 2010 